\title{
Problems, Suggestions and Last Trends Related to Salgam Beverage which is Traditional Product of Turkey
}

\author{
Hasan Tangüler ${ }^{1, a, *}$, Selin Özge Dinç, ${ }^{1, b}$,Sermet Can Beylikci²,c \\ ${ }^{1}$ Food Engineering Department, University of Niğde Omer Halisdemir, 51245 Niğde, Turkey \\ ${ }^{2}$ Food Engineering Department, Manisa Celal Bayar University, 45140 Manisa, Turkey
}

${ }^{*}$ Corresponding author

\begin{tabular}{l|l}
\hline A R T I C LE I N F O & A B S T R A C T \\
\hline Review Article & $\begin{array}{l}\text { Salgam (Şalgam, shalgam) is our conventional fermented purple carrot beverage. Purple carrot } \\
\text { (Daucus carota) is the basic raw material, and other raw materials used in the production are } \\
\text { sourdough/ bakers' yeast, salt (rock), bulgur flour and/or turnip (Brassica rapa L.). There are two } \\
\text { fermentations that occur due to microorganisms (lactic-acid bacteria and yeast) that are effective } \\
\text { during production; primarily lactic-acid fermentation and ethyl alcohol fermentation. It is very } \\
\text { popular in our country, especially southerly cities of Turkey. Although shalgam is mostly produced } \\
\text { and consumed in Mersin/İcel, Osmaniye, Hatay-Antakya and Kahramanmaras cities, the most known } \\
\text { and loved city is the Adana. Lately, it has begun to be consumed almost every parts of Turkey. In } \\
\text { addition, it is sold in the cities where the densities of the Turks in Europe. The aim of this review } \\
\text { article is to give information about the production methods of salgam, scientific studies and recent } \\
\text { trends, problems related to salgam and solutions. }\end{array}$ \\
$\begin{array}{l}\text { Accepted : } 15 / 06 / 2020 \\
\text { Seywords: }\end{array}$
\end{tabular}

) beverage

Daucus carota

Production method

Turkish traditional foods

Purple carrot beverage

Türk Tarım - Gıda Bilim ve Teknoloji Dergisi, 8(6): 1266-1271, 2020

\section{Türkiye'nin Geleneksel Ürünü Salgam İçeceği İle İlgili Sorunlar, Öneriler ve Son Trendler}

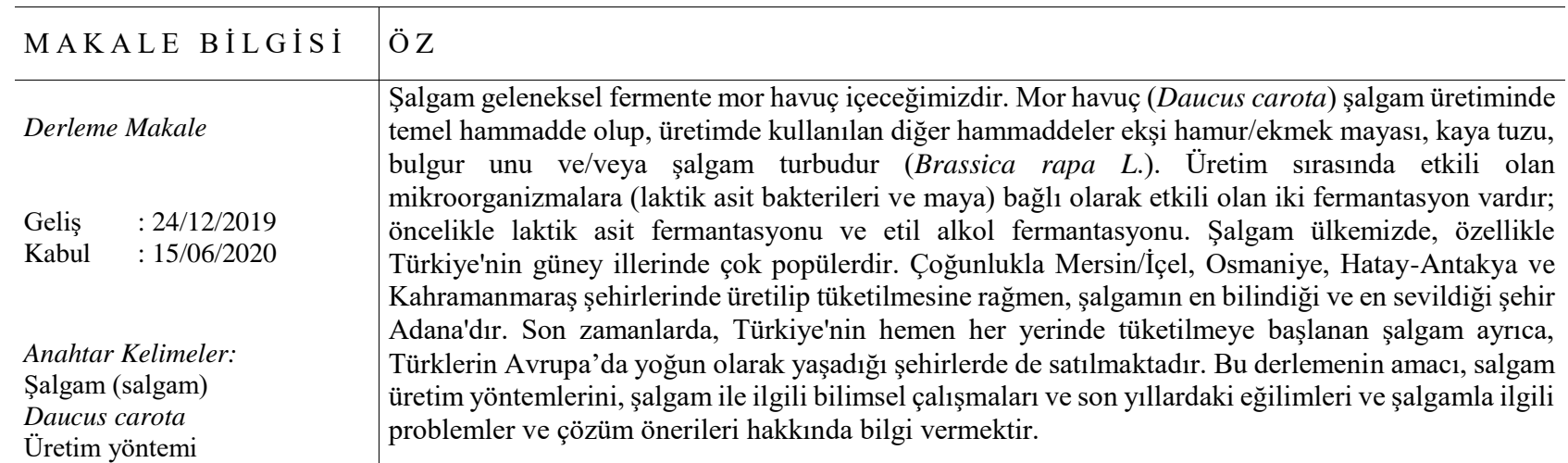

Uretim yöntem

Türk geleneksel içeceği

Mor havuç içeceği 


\section{Introduction}

Salgam is a beverage fermented by mainly lactic acid bacteria and also yeast. It is a conventional Turkish sour soft beverage. Although salgam drink is quite popular in south of Turkey, especially in Adana, Osmaniye, HatayAntakya, İçel and Maraş, lately is consumed throughout the Turkey. It has recently begun to be consumed in other cities of Turkey (such as İstanbul, Ankara, İzmir, Bursa, Konya and the districts bound to these cities) (Erten et al., 2008; Erten and Tanguler, 2010). On the other hand, particularly in the capitals of Europe where Turkish people live intensely have also sold in markets (Tanguler and Erten, 2012a; Tanguler et al., 2015).

Traditionally, salgam which is very popular in Turkey, produced at home for family or in small quantities. However, it is also made industrially (Canbas and Fenercioglu, 1984). Salgam is very popular in Turkey. At least, salgam is enjoyed as much as other beverages and consumption has reached important quantities. It is generally consumed with local foods (such as kebab) and beverages (such as Raki, which is the conventional Turkish anise flavored distillate alcoholic beverage) and as a refreshing drink (Erten et al., 2008; Bulur, 2010).

Salgam is a reddish and sourish soft traditional drink in which primarily lactic acid bacteria (Lactobacillus plantarum and etc.) and also yeast (Saccharomyces, S., cerevisiae) effective in fermentation. That beverage is achieved by the mainly lactic acid fermentation of roots of purple carrot (anthocyanin group, Daucus carota ssp. sativus var. atrorubens Alef.), sourdough (or sometimes bakers' yeast, $S$. cerevisiae), rock-salt or sea salt, bulgur flour (broken wheat, bran, setik), turnip-root (Brassica rapa L.) and drinkable water (Erten and Tanguler, 2012).

\section{The Production Methods of Salgam}

There is no standard manufacturing process currently used in salgam beverage manufacture. The production procedure differs depending on the producer or operator. On the other hand, there are two principal techniques industrially used in production of salgam: The conventional method (dough fermentation and carrot/main fermentation) and the direct (fast) method (without dough fermentation). Unfortunately, there is no commercially available starter culture isolated from autochthonous or allochthonous environment as we know. In addition, there are very few studies on the isolation and identification of microorganisms in salgam. The number of studies related to usage in the salgam production of lactic acid bacteria isolated from these studies is very scarce. Because of these, starter culture is not used for the production of salgam in industry (Erten and Tanguler, 2012; Tanguler and Erten, 2013). However, rarely is used a different method. Salgam beverage from a previous manufacture batch is occasionally utilized as a starter culture; its ratio (10-15\%) depends on the manufacturer, and also season and temperature (Canbas and Fenercioglu, 1984). On the other hand, it was determined in a study that Lactobacillus plantarum, Lactobacillus fermentum, and Lactobacillus paracasei have potential as autochthonous salgam starter for commercial manufacture (Tanguler and Erten, 2013).

\section{Conventional Method}

This method is carried out in 2 steps namely first fermentation and second fermentation (Figure 1). The first one is called sourdough or dough fermentation. It is made for the proliferation of microorganisms which effective in fermentation. Therefore, the mixture of aforementioned raw materials is allowed for dough fermentation. Fermentation is carried out at ambient temperature $\left(25^{\circ} \mathrm{C}\right)$ for 3-5 days depending on the manufacturer for the formation of dough (Tanguler and Erten, 2012b). After dough fermentation, fermented dough mixture is extracted with drinkable water almost 3-5 times to be able to use for carrot (main) fermentation. And then, liquid extract is mixed with sliced purple carrots pieces, rock-salt, cut-off turnip-root and drinkable water in a fermentation vessel to perform the $2^{\text {nd }}$ fermentation (Erten and Tanguler, 2012). Second fermentation is called carrot or main fermentation. It is generally carried out at ambient temperature $\left(10^{\circ} \mathrm{C}\right.$ $35^{\circ} \mathrm{C}$ ) for three to ten days (Canbas and Deryaoglu 1993; Erten et al. 2008).

\section{Fast Method}

The first fermentation stage is not performed in fast salgam production method. Sliced purple carrots pieces, rock salt, if available cut-off root of turnip, bakers' yeast, and drinkable water are mixed in a vessel (Figure 2). Fermentation which is called main fermentation is performed at room temperature $\left(10-35^{\circ} \mathrm{C}\right)$ for three to ten days.

Salgam fermentations are traditionally performed in wooden vessels. However, fiberglass, plastic or stainless steel tanks are used in modern processes. At the end of process, fermented product is taken out from the tank and it is typically put up for sale in closed glass or plastic bottles, and besides in open containers (Erten et al., 2008; Erten and Tanguler, 2012).

\section{Scientific Research on Salgam Reported in The Last 20 Years}

Published reports on salgam are increasing day by day. They are mainly on enzyme application (Miisoglu, 2004), possibility of clarification of salgam beverage (Nesanir, 2004), anthocyanin quantity and quality of salgam (Turker et al., 2007), composition of salgams produced by different methods (Tanguler, 2010), preservatives in salgam beverages obtained from Adana Market (Ozturk, 2009), inactivation of yeasts causing deterioration in salgam by heat treatment (Ozer, 2009) and by using pulsed UV light (Karaoglan, 2013; Karaoglan et al., 2017), sterile filtration, storage for 6 months at $4^{\circ} \mathrm{C}$ and volatile aroma compounds (Tanguler, 2010), biogenic amine levels of salgam (Ozdestan and Uren, 2010), the impact of temperature on the formation and amount of some biogenic amines (Yaldırak, 2011), salgam combination manufactured in Turkey and their suitability to food regulations (Çakır, 2011; Gök, 2011), the selection of the strains producing the phenolic acid decarboxylase enzymes from lactic-acid bacteria isolated from salgam (Okcu, 2011), isolation and identification of lactic-acid bacteria during fermentation, and fermented salgam (Okcu, 2011; Tanguler and Erten, 2012a; 2012b; Tanguler et al., 2015), major and minor 
elements (Y1lmaz-Ersan and Turan, 2012), effect of yoghurt serum on nutritional properties and fermentation of salgam (Cankurt et al., 2012), selection of potential autochthonous starter cultures (Tanguler and Erten, 2013), total phenolic content and antioxidant capacity (Baser, 2013), comparison of microbial, chemical and sensorial properties of salgams produced by various production practices and possibilities of autochthonous starter culture usage (Tanguler et al., 2015), impact of distinct quantities of purple carrot root (Tanguler et al., 2014a), effect of purple carrot size usage (Tanguler et al., 2014b), the effect on the sensory properties of low level heat treatment (Ozer and Coksoyler, 2014), reducing the amount of salt in salgam (Güven, 2018; Agirman and Erten, 2018), possibilities of using purple grape pomace in salgam production (Bulut, 2018), uniformity and degradation kinetics of anthocyanins (Bozdogan and Yasar, 2019), composition of phenolic materials, capacity of antioxidant and also in vitro bioaccessibility of salgam during fermentation (Toktaş, 2016).

\section{First stage}

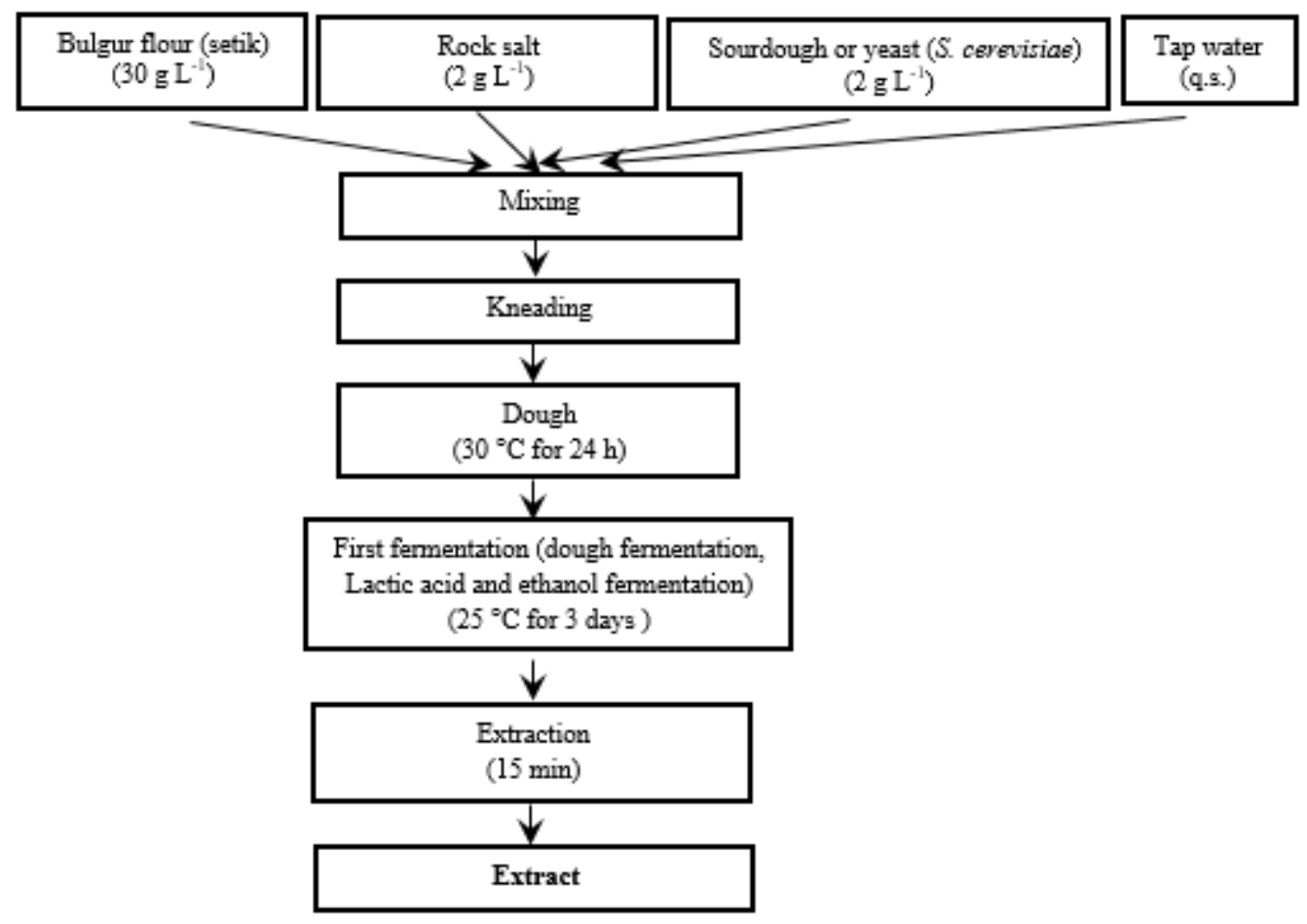

Second stage

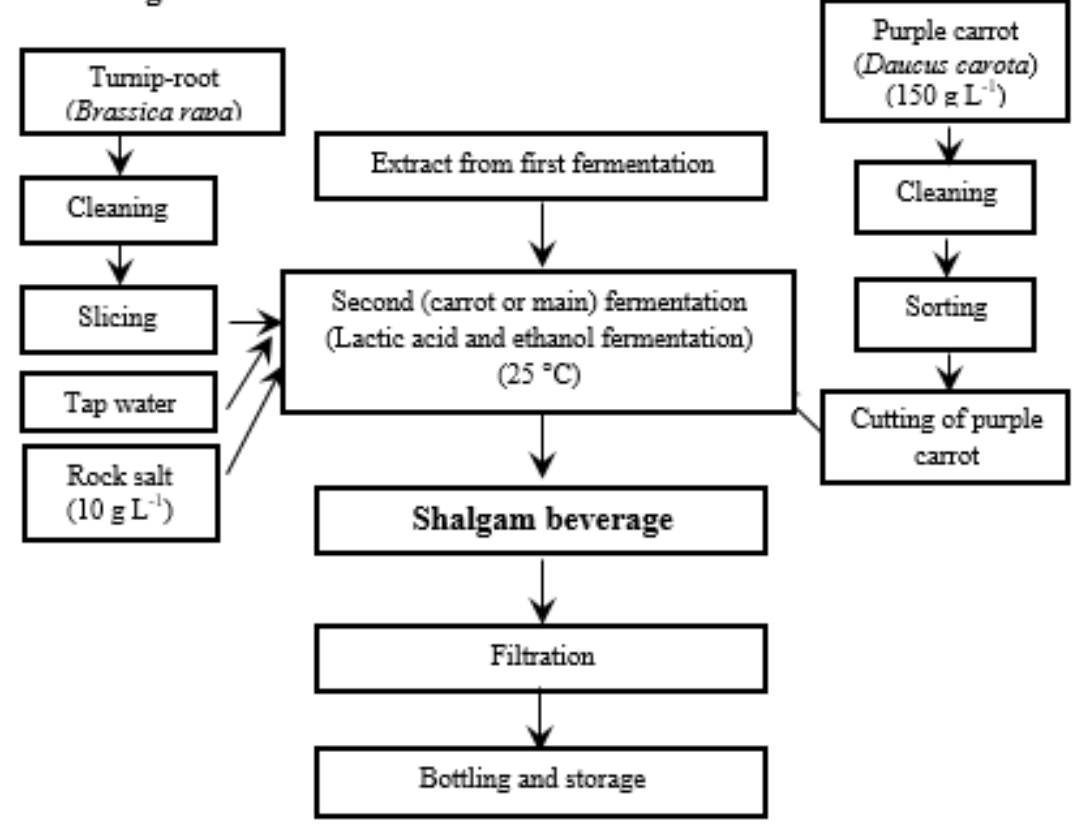

Figure 1. Conventional method 


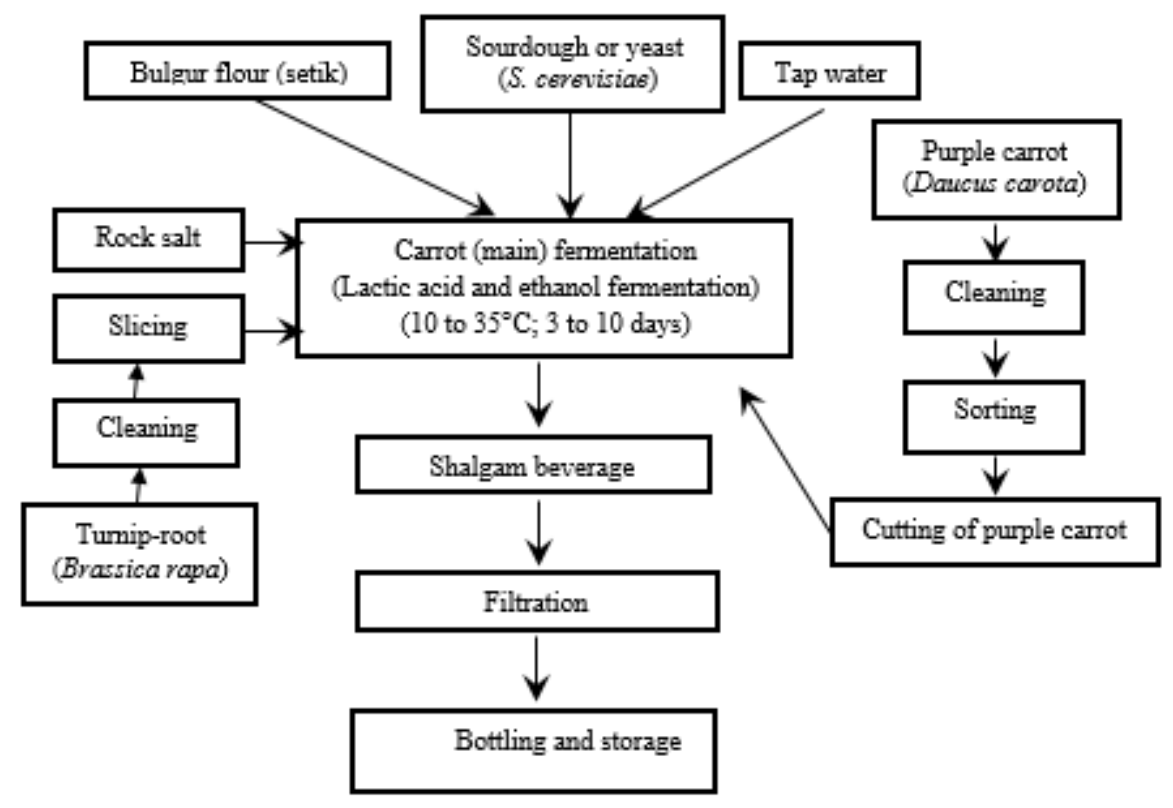

Figure 2. Fast method

On the other hand, new trend studies on salgam are being made. Boyaci-Gunduz et al (2018) produced instant salgam powder from fermented salgam. They have analyzed its some physicochemical and sensorial properties. In addition, they detected that the instant salgam had close scores with the sensory properties of the fermented salgam. However, new trend studies on salgam are on antiproliferative properties of salgam (Ekinci et al., 2016) and especially antiproliferative activity against a colon cancer cell line (Özcan et al., 2012), cytotoxic, antimicrobial and DNA breaking activity (Tazehkand and Valipour, 2019).

\section{Problems Related to Salgam}

Microorganisms such as "lactic acid bacteria" and "yeasts" found in the medium during fermentation of salgam play a considerable role in the chemical, microbial, physical and sensorial features of salgam beverage. On the other hand, some of them (yeasts) can be harmful at the same time. For example, Candida inconspicua can cause problems, and especially spoilage in salgam beverage by metabolizing lactic acid formed and rising the $\mathrm{pH}$. Due to this deterioration, some undesirable flavor, taste and odor may occur in the salgam beverage (Karaoglan, 2013; Tanguler et al., 2015).

That spoilage is a serious problem in salgam industry and shortens the shelf life of salgam. The short shelf life is very important in terms of the salgam beverage industry, perhaps one of the most important problems. The shelf life is usually very short as heat treatments such as pasteurization are not applied. Its shelf life is approximately 90-120 days even in a closed plastic tank or in a container or glass bottle during cold air storage at low temperature (such as $+4^{\circ} \mathrm{C}$ ) (Erten et al., 2008; Tanguler 2010). On the other hand, shelf life of salgam could be prolonged by heat treatment application (pasteurization) according to the TS 11149 Turkish Standards (T.S.E.,
2003). Nowadays, a few manufacturers use pasteurization process for extend shelf life of salgam. However, if heat treatment is applied, some problems related to the salgam occur. The most important problem occurs in sensory characteristics of salgam. It observes deterioration in sensory properties of heat-applied salgam due to cooked carrot taste and odor. For this reason, it is not preferred by consumer people (Canbas and Fenercioglu, 1984). Other studies have also been carried out to increase the shelf life of the salgam. In these studies, especially ultraviolet pasteurization (Dogan, 2017) ultrasonication and high pressure processing pasteurization (Ates, 2019) were used.

In addition to thermal, UV, ultrasonication and high pressure process, its shelf life could be also extended by using some chemical additives (Erten et al., 2008). A maximum $200 \mathrm{mg} / \mathrm{L}$ of sodium and potassium salts of benzoic acid (Na-benzoate, K-benzoate) as preservatives may be used to extend its storage period according to Turkish Food Codex-Food Additives Other Than Coloring and Sweeteners Directive. The usage of chemical prophylactics other than benzoic acid in salgam to extend shelf life is not allowed lawfully (Anonymous, 2008).

However, there is a possibility that many salgam beverages contain different food preservative than allowed to use in salgam. In addition, they contain preservative more than the value specified. For example, natamycin is generally utilized in salgam production as a preservative, and it is not permitted to use as a food preservative in salgam Legislation in Turkey (Ozer and Coksoyler, 2014). Therefore, the consumers are misled by the use of food preservatives and additives which pose great risks to consumers' health. On the other hand, if salgam is subjected to membrane filtration application ready-todrink salgam could be preserved at $4{ }^{\circ} \mathrm{C}$ and $20^{\circ} \mathrm{C}$ for 150 180 days without any deteriorations in its characteristics. These characteristics can be specified as chemical, physical, microbiological and sensorial characteristics (Tanguler, 2010). 
Other problems with regard to salgam are marketing, promotion, advertising and raw materials (especially purple carrot and turnip). It is still not known in some parts of Turkey or less known and therefore is not preferred. In these regions, presentations and advertisings should be done. On the other hand, a shortage of raw materials began together with the increase of production. Especially, purple carrot price has dramatically increased.

\section{Conclusion and Suggestions}

Salgam juice is a conventional Turkish lactic-acid fermented purple carrot drink. Its popularity is growing day by day. Parallel to the increase of popularity, problems are also arising. To solve these problems, first of all, the method of salgam production in commercial plants must be performed under sterile circumstances. In addition, standard manufacturing technique must be developed, studies with regard to usage of autochthonous starter cultures should be performed to achieve the desired fermentation parameters and new studies related to increase the shelf-life should be increased. On the other hand, in the future, studies on the determination of probiotic properties of bacteria in salgam and determination of the survival time of some known probiotic bacteria in salgam, research should be done about solving health problems.

\section{References}

Agirman B, Erten H. 2018. The influence of various chloride salts to reduce sodium content on the quality parameters of shalgam (salgam): A traditional Turkish beverage based on black carrot. J Food Qual, 2: 1-11.

Anonymous. 2008. Renklendiriciler ve Tatlandırıcılar Dışındaki Gıda Katkı Maddeleri Tebliği. Türk Gıda Kodeksi Yönetmeliği Tarım ve Köyişleri Bakanlığı, Tebliğ No: 2008/22 Resmi Gazete, 22/05/2008-26883.

Ates C. 2019. Fermente şalgam içeceğinin pastörizasyonunda ultrasonikasyon ve yüksek hidrostatik basınç kullanımının kalite özellikleri ve raf ömrü üzerine etkisi. Yüksek Lisans Tezi, Bolu Abant İzzet Baysal Üniversitesi Fen Bilimleri Enstitüsü, 477S, Bolu.

Baser GM. 2013. Biological and chemical characterization of salgam juice. MSc Thesis, Yeditepe University, P110, İstanbul.

Boyaci-Gunduz CP, Agirman B, Erten H. 2018. Salgam powder production from fermented salgam: A traditional Turkish lactic acid beverage. Carpath. J Food Sci Technol, 10(2): 3747.

Bozdogan A, Yasar K. 2019. Degradation kinetics of anthocyanins in shalgam beverage. Turkish Journal of Agriculture- Food Science and Teknology, 7(2): 282-285.

Bulur A. 2010. Çukurova bölgesinde üretilen boğma rakıların kimyasal bileşimleri üzerine bir araştırma. Yüksek Lisans Tezi, Çukurova Üniversitesi, 80S, Adana.

Bulut AN. 2018. Şalgam suyunun fenolik profil ve antioksidan aktivitesi üzerine farklı oranlarda siyah üzüm posas1 kullanımı etkisinin belirlenmesi. Yüksek Lisans Tezi, Selçuk Üniversitesi Fen Bilimleri Enstitüsü, 60S, Konya.

Çakır F. 2011. Ülkemizde üretilen şalgam sularının bileşimleri ve gıda mevzuatına uygunlukları üzerine bir araştırma. Yüksek Lisans Tezi, Namık Kemal Üniversitesi Fen Bilimleri Enstitüsü Gıda Mühendisliği Anabilim Dalı 53S, Tekirdağ.

Canbaş A, Deryaoğlu A. 1993. Şalgam suyunun üretim tekniği ve bileşimi üzerinde bir araştırma. Doğa- Turk J Agric For, 17: 119-129.
Canbas A, Fenercioglu H. 1984. Şalgam suyu üzerine bir araştırma. Gıda, 9: 279-286.

Cankurt H, Sağdıç O, Yetim H. 2012. Using yoghurt serum in the production of fermented carrot juice. Geleneksel Gidalar Sempozyumu, Konya, 10-12 Mayis, S 643.

Dogan K. 2017. Optimization of ultraviolet pasteurization conditions of salgam (şalgam) juice and determination of its shelf life. Master Thesis, Y1ld1z Technical University Institute of Science P99, Istanbul.

Ekinci FY, Baser GM, Özcan E, Üstündag ÖG, Korachi M, Sofu A, Blumberg JB, Oliver Chen CY. 2016. Characterization of chemical, biological and antiproliferative properties of fermented black carrot juice salgam. Eur Food Res Technol, 242: 1355-1368.

Erten H, Tanguler H, Canbas A. 2008. A traditional Turkish lactic acid fermented beverage: shalgam (salgam). Food Rev Int, 24: 352-359.

Erten H, Tanguler H. 2010. Fermented Vegetable Products. In: N Aran, editor. Food Biotechnology. Nobel Publication: Istanbul, P 241-278. (In Turkish).

Erten H, Tanguler H. 2012. Şalgam (Salgam). Ed: Hui YH, Evranuz E.Ö. Handbook of Plant-Based Fermented Food and Beverage Technology, $2^{\text {nd. }}$ Press CRS Press, London-New York, PP: 657-664.

Gök S. 2011. Adana İlinde Satışa Sunulan Şalgam Sularının Kalite Özelliklerinin Ve Türk Gida Kodeksine Uygunluğunun Belirlenmesi. Yüksek Lisans Tezi, Kahramanmaraş Sütçü İmam Üniversitesi Fen Bilimleri Enstitüsü 60s, Kahramanmaraş.

Güven N. 2018. Siyah havuç suyu konsantresi ve peyniraltı suyu kullanılarak tuzu azaltılmış şalgam suyu üretim imkânlarının araştırılması. Yüksek Lisans Tezi, Erciyes Üniversitesi Fen Bilimleri Enstitüsü, P 86, Kayseri.

Karaoglan A. 2013. Inactivation of yeasts which causes spoilage of salgam beverage by using pulsed UV light. Msc Thesis, Cumhuriyet University, P115, Turkey (In Turkish).

Karaoglan HA, Keklik NM, Işıklı ND. 2017. Modeling inactivation of Candida Inconspicua isolated from turnip juice using pulsed UV light. J Food Process Eng, 40:1-9.

Miisoglu D. 2004. Effect of enzyme application on the yield and quality during salgam beverage production. MSc Thesis, Harran University P68, Sanliurfa, Turkey (In Turkish).

Nesanir M. 2004. The possibility of clarification of salgam beverage. MSc Thesis, Harran University P59, Sanlıurfa, Turkey (In Turkish).

Okcu G. 2011. Geleneksel olarak üretilen şalgam suyundan laktik asit bakterilerinin izolasyonu, tanımlanmasi ve fenolik asit dekarboksilaz enzim üreten suşlarin seçimi. Yüksek Lisans Tezi, Ankara Üniversitesi Fen Bilimleri Enstitüsü 61S, Ankara, Türkiye.

Özcan E, Aydin K, Başer G, Güçlü-Üstundağ O, Korachi M, Ekinci F. 2012. Evaluation of salgam juice antiproliferative activity against a colon cancer cell line. New Biotechnol. 29:115.

Ozdestan O, Uren A. 2010. Biogenic amine content of salgam: a traditional lactic acid fermented Turkish beverage. J Agric Food Chem, 58:2602-2608.

Ozer N, Çoksöyler N. 2014. Düşük düzeyde isıl işlemin şalgam suyunun duyusal özellikleri üzerine etkisi. 4. Geleneksel Gidalar Sempozyumu, Adana, 17-19 Nisan, 120-123.

Ozer NO. 2009. Inactivation of spoilage factor wild yeasts by heat treatment in salgam beverage to prolong the shelf-life. MSc Thesis, Yüzüncü Y1l University P158, Van, Turkey (In Turkish).

Ozturk O. 2009. A research on the composition of salgam beverages obtained from Adana market. MSc Thesis, Cukurova University, P43, Adana, Turkey (In Turkish).

T.S.E. 2003. TS 11149 Şalgam Suyu Standard1, Türk Standardları Enstitüsü, Ankara. 
Tanguler H, Erten H. 2012a. Chemical and microbiological characteristics of salgam (şalgam); A traditional Turkish lactic acid fermented beverage. J Food Qual, 35: 298-306.

Tanguler H, Erten H. 2012b. Occurrence and growth of lactic acid bacteria species during the fermentation of salgam (shalgam): A traditional Turkish fermented beverage. LWT-Food Sci Technol, 46: 36-41.

Tanguler H, Erten H. 2013. Selection of potential autochthonous starter cultures through lactic acid bacteria isolated and identificated from salgam: A traditional Turkish fermented beverage. Turk J Agric For, 37: 212-220.

Tanguler H, Gunes G, Erten H. 2014a. Influence of addition of different amounts of black carrot (Daucus carota) on salgam quality. J Food Agric Environ, 12(2): 60-65.

Tanguler H, Saris PE, Erten H. 2015. Microbial, chemical and sensory properties of salgams made using different production methods. J Sci Food Agric, 95(5): 1008-1015.

Tanguler H, Utus D, Erten H. 2014b. Effect of black carrot size usage on the quality of salgam (salgam): A traditional Turkish lactic acid fermented beverage. Indian J Tradit Know, 13(4): 647-653. https://hdl.handle.net/11480/4117

Tanguler H. 2010. Şalgam suyu üretiminde etkili olan laktik asit bakterilerinin belirlenmesi ve şalgam suyu üretim tekniğinin belirlenmesi. Doktora Tezi, Çukurova Üniversitesi Ziraat Fakültesi, 367S, Adana.
Tazehkand MN, Valipour E. 2019. Cytotoxic, Antimicrobial and DNA breaking activity of salgam. Indian J Biochem Bio, 56(2): 169-174

Toktaş B. 2016. Effect of fermentation on phenolic content, anthocyanin stability, antioxidant capacity and in vitro bioaccessibility during salgam (şalgam) beverage production. MSc Thesis, Istanbul Technical University Graduate School of Science Engineering and Technology P44, İstanbul, Turkey (In Turkish).

Turker N, Aksay S, Istanbullu O, Artuvan E. 2007. A study on the relation between anthocyanin content and product quality: Salgam as a model beverage. J Food Qual, 30: 953-969. https://doi.org/10.1111/j.1745-4557.2007.00171.x

Yaldırak G. 2011. Doğal fermantasyonla üretilen şalgam suyunda farklı fermantasyon sıcaklığının biyojen amin oluşumu üzerine etkisi. Yüksek Lisans Tezi, Sakarya Üniversitesi Fen Bilimleri Enstitüsü, 58S, Sakarya, Türkiye.

Yilmaz-Ersan L, Turan MA. 2012. Major and minor element concentrations in fermented salgam beverage. Int $\mathrm{J}$ Food Prop, 15: 903-911. 